\title{
Multi-Layered Language Policy and Translanguaging Space a Mother Tongue Classroom in Primary School in Sweden
}

\author{
Åsa Wedin*a, Jenny Rosén ${ }^{b}$, Boglárka Straszer ${ }^{\circ}$
}

$\begin{array}{ll}\text { Received } & : \text { 14 June } 2020 \\ \text { Revised } & : \text { 23 March } 2021 \\ \text { Accepted } & : \text { 15 June 2021 } \\ \text { DOI } & : \text { 10.26822/iejee.2021.222 }\end{array}$

Corresponding Author: Åsa Wedin, Dalarna University, SE-791 88 Falun, Sweden,

E-mail: awe@du.se

ORCID: https://orcid.org/0000-0002-2992-0818

bJenny Rosén, Stockholm University, Stockholm, Sweden E-mail: jenny.rosen@isd.se

ORCID: https://orcid.org/0000-0001-7937-3325

`Boglárka Straszer; Dalarna University, Sweden E-mail: bsr@du.se

ORCID: https://orcid.org/0000-0002-0011-1689

\begin{abstract}
This article is aimed to demonstrate how language policy at the local school level may create space for translanguaging. Focus is on a Mother Tongue (MT) classroom for Somali in a primary school in Sweden by way of an analysis of layers of language policy, with focus on spatial aspects. The empirical material consists of policy documents, interviews and observations documented through field notes and photographs from an MT Somali classroom with grade six students. Through the use of a framework of language policy as layered and linguistic landscaping with a focus on aspects of time, place and social factors, the analysis shows how the mother tongue classroom may constitute a demarcated room, while simultaneously interacting with other spaces both inside and outside school. The understanding of policy as layered made power relations visible in terms of language that moves between layers. It also made visible how school discourses shift between micro/macro, management/practice and inside/outside in the creation of space dominated by Somali and Swedish. It became apparent that an environment that supports the use of Somali inside the MT classroom may increase the likelihood of the pupils using Somali outside the classroom.
\end{abstract}

Keywords:

Language Policy, Mother Tongue Education, Sweden, Primary School

\section{Introduction}

In the 1960s, Sweden has mandated Mother Tongue Tuition (MTT), previously called home language instruction, to students in compulsory school who use another language than Swedish at home. The overall objective, as described in the national curriculum for compulsory school, is to support pupils in the development of their mother tongue (SNAE, 2018: 86). The common language of instruction in Swedish primary school is Swedish, with English being a core subject. MTT is offered for students who use another language than Swedish in their home setting but is not an 
obligatory subject (SFS, 2010:800; see also Hyltenstam \& Milani 2012). The aim of the subject is according to the national curriculum to help students to "develop knowledge in and about the mother tongue" (SNAE, 2018: 86). The concept mother tongue (MT) may be problematic for several reasons, but we will use it in this article to refer to the specific school subject in the Swedish national curriculum.

Despite its long tradition and the strong support it receives in both official contexts and research, reports (SI, 2012; Spetz, 2014) and research relating to MT (Avery, 2016; Ganuza \& Hedman, 2015; Lainio, 2013; Reath Warren, 2013;) show deficiencies in the implementation of MT policy. Previous studies have highlighted the often marginalised role of MT teachers in the Swedish school context in terms of the ambivalent position of the school subject, lack of MT teacher education, employment status and relation to other teachers categories (Ganuza \& Hedman, 2015; Jonsson-Lilja, 1999; Reath-Warren, 2013; Wigerfelt, 2004). There is a clear gap between the ambitions expressed in official policy and the reality of MT, as described in research and reports on the organisation of MT classes (see, for example, Norberg Brorsson \& Lainio, 2015; SI, 2012). Reports point towards extensive structural problems (for example, Spetz, 2014) and the impossibility of achieving the ambitious goals relating to MT as stated in the Swedish Education Act, the national curriculum and syllabi for the MT, when the limited number of allotted teaching hours is considered. (See also Rosén, Straszer, \& Wedin 2019a.)

Research by, for example, Baker (2011), Cummins (2017) and García (2009) emphasize the importance of opening spaces for students with a migrant background to use and develop their linguistic repertoire by creating what (Wei, 2011) termed translanguaging spaces, that is arenas for translanguaging practices created through processes of translanguaging. Earlier studies (Straszer, Rosén, \& Wedin, 2020) positioned MT classrooms as spaces where complex diaspora situations and nationalities may be negotiated and where language hierarchies and issues of language policy are made more visible (Straszer, Rosén, \& Wedin, submitted). In this article we direct our focus towards local language policy and its influence on spatial aspects of MT in a primary school in Sweden. The aim of the article is to study how language policy at the local school level may create space for translanguaging, and we do this by focussing on a selected MT classroom.

\section{Theoretical basis}

The theoretical framework of this study includes a critical and post-structural perspective on education and language that highlights questions of power, such as voice, agency and investment (Block, 2007; Norton,
2013; Pavlenko \& Blackledge, 2004). Considering the marginalised role of MT identified in previous studies, aspects of power and empowerment are important when trying to understand its marginalised role in school. An important requirement for successful spatial integration of MT is local school policy, where physical, temporal and social space is created for MT. We aim to analyse how local school policy may create space for translanguaging, with focus on one specific MT classroom. Here we will build on $\mathrm{Li}$ Wei's use of the concept translangauging space described as being both an arena for translanguaging practices and a space created through the process of translanguaging. Moreover, translanguaging "creates a social space for the multilingual language user by bringing together different dimensions of their personal history, experience and environment, their attitudes, beliefs and ideology, as well as their cognitive and physical capacity into one coordinated and meaningful performance, which then becomes a lived experience" (Wei, 2011, p. 1223). For the analysis of spatial aspects of language policy, linguistic landscaping (see Blommaert, 2013; Straszer, 2017; Straszer et al., 2020) will be used, where issues relating to space in terms of i) physical/material, ii) temporal and iii) social aspects are considered. We will first present the theoretical ground used here for the study of language policy and then the basis for translanguaging space.

\section{Understanding language policy at the local school level through layers}

Based on a critical theoretical framework, social power relations and their mirroring in educational structures and interaction patterns for students' learning and identity processes depend on how language policy is implemented explicitly as well as implicitly (Hornberger \& Johnson 2017). Building on Cummins (2005) and Spolsky (2004), we thus consider language policy as both official documents as well as implicit language norms and perceptions. Ricento and Hornberger (1996) used the metaphor of an onion to create an understanding of policy as layered, and Hornberger and Johnson (2017) developed the metaphor further by talking about policy as opening or closing spaces for multilingual practices.

Bonacina-Pugh (2012) described the relation between policy and practice as comprised by three closely intertwined elements: 1) management, 2) ideology and 3) practised language policy. Language policy is constructed and negotiated in and between these layers. In our case the declared language policy, such as the Swedish Education Act (SFS 2010:800), and the perceived policy among school leaders, teachers and students, as well as their perceptions about language, affect the opportunities students have to use and develop their linguistic repertoire on a daily basis, 
both inside and outside the classroom. Thus, language policy influences spaces for multilingualism through interaction between these layers. Understanding policy as consisting of multiple layers (see Blommaert \& Maly, 2014) enables an analysis of agentive powers influencing and intersecting each other in complex ways (Ricento \& Hornberger, 1996). Thus, in this article we follow Hornberger and Johnson (2017) by creating understanding of how space for multilingual practices such as translanguaging may be opened and closed, with focus on the importance of how actors act and move between policy layers is in focus.

The three layers illustrate the close relation between practice, an explicit language policy and attitudes in relation to practised language policy, while the importance of understanding the role of language policy in educational settings is emphasized. Here we will use Bonacina-Pugh's model to analyse the influence of language policy on the MT classroom as space for multilingual practices, focusing the management level and practices at the classroom level. Thus, Bonacina-Pugh's third element, the perceptions of those involved, will not be analysed in depth here as our focus is on the relation between managed and practised language policy at the local school level.

\section{Space for translanguaging}

Several scholars (García, 2017) emphasise the importance of creating spaces for students' multiple language resources. In particular, they highlight the importance of supporting students diverse linguistic repertoires that may differ from the language of instruction- languages that are often invisible and considered less important in the educational setting. With our focus on spatial aspects of the MT classroom, we see physical, temporal and social aspects as valuable for an understanding of how spaces are opened and closed for students' diverse linguistic repertoires.

According to Rönnlund and Tollefsen (2016), schools and classrooms may be perceived as public spaces, that is as ideologically and institutionally designed to "do something" (Rönnlund \& Tollefsen, 2019, p. 163, our translation). When people appropriate these rooms, it becomes interesting to distinguish between on the one hand a dominant and on the other hand an appropriated space (Lefebvre, 1991). According to Lefebvre, there are clear power relations between dominant and appropriated rooms where the dominant is superior to the appropriated. At the same time, appropriated rooms are continuously created and have an important role in society. One example is graffiti, which may be perceived to be an example of appropriated space that persists despite thwarting authorities (see Straszer \& Wedin, 2018).

The classroom constitutes a social space, where the particular place, the physical classroom at a certain point in time, displays a specific mix of social relations, including a particular sense of belonging (cf. Wei, 2011, pp. 1222-1223). Li Wei (2011, p. 1223) uses translanguaging space both for a social space that is open for translanguaging as a social practice as well as for the space created through translanguaging practices. Translanguaging space in educational settings may thus be understood to be a space where students' linguistic repertoires are acknowledged and valued. This means that translanguaging spaces are physical, timely and social spaces and, according to Zhu, Li and Lyons (2017), express the dynamic, complex and interconnected nature of multilingual interaction where new meanings are co-produced. (See also Straszer et al. submitted)

To develop knowledge about spatial aspects of MT classrooms, linguistic landscaping as theory and method is relevant (Landry \& Bourhis, 1997). The concept has been used principally to show how public spaces are symbolically constructed, by the description and interpretation of how language is visually used in multilingual settings (Ben-Rafael et al., 2006; Shohamy \& Gorter, 2009; Blommaert, 2013). Linguistic landscaping as a research method may contribute to an understanding of linguistic hierarchies. It may also make visible what languages are perceived to be relevant and/or are given status in a certain space so that conclusions can be drawn as to how it is influenced by local language policies. Lately, there has been increased interest in landscaping within the context of school, schoolscaping (e.g. Szabó, 2015; Straszer, 2017; Straszer et al. 2020; Straszer \& Kroik, in press). The concept schoolscape is defined by Brown (2012, p. 282) as being a "school-based environment where place and text, both written (graphic) and oral, constitute, reproduce, and transform language ideologies".

Using schoolscaping as an analytical tool, we do not approach multilingualism as something that individuals have or do not have; rather, it is perceived as something that the environment can make possible by way of organisational structures and interactional patterns. This implies the perception that the classroom does something to those who inhabit it, namely students and teachers, and vice versa as these in interaction semiotically create and modify the room. As emphasized by Blommaert et al. (2005), the space is there before any activity starts and it triggers certain activities and actions. At the same time, the space is inhabited and appropriated by people, who may be teachers and students whose goals may differ. The room may also have restrictions concerning 
participation and repertoire, such as which language should be used, and may have various time-related restrictions, which actualises issues of language policy, such as issues regarding who may enter the room, who is given voice and what spaces for diverse language resources are opened and closed.

The analysis of language policy at the local school level with a focus on space enables the study of conditions and processes at the micro level as contingent resources in relation to the macro level.

To study how language policy at the local school level may create space for translanguaging in one specific MT classroom, the following research questions will guide the analysis:

1. What language policies at the management level become visible in relation to the MT classroom?

2. What practised language policy becomes visible through physical, temporal and social aspects of the specific MT classroom?

The answers to these questions will then allow for an analysis of how the multilayered language policy at this particular primary school in Sweden facilitates the MT classroom as a translanguaging space.

\section{Method and data}

The empirical material that was analysed was produced in two research projectsi. The first project was an action research project in a primary school, which is here called Forest Schooli. The second project focused on MT and Study Guidance through the Mother Tongue (SGMT) and was carried out in two municipalities and at five schools, of which Forest School was one. The data analysed here is from Forest School. Other development projects were carried out at Forest School at the same time, and these were led by the school's head teacher and teachers of Swedish as a second language (see Wedin, 2017; Wedin \& Wessman, 2017). These development projects were not explicitly part of the two research projects; however, because they focused on developing local school policy, which was monolingual Swedish-only, into becoming a multilingual policy that incorporated Table 1.

Material used

\begin{tabular}{|c|c|c|c|c|c|c|}
\hline & $\begin{array}{l}\text { Classroom obser- } \\
\text { vations with field } \\
\text { notes }\end{array}$ & $\begin{array}{l}\text { Video-re- } \\
\text { cordings }\end{array}$ & Photographs & $\begin{array}{l}\text { Policy docu- } \\
\text { ments }\end{array}$ & Interviews & $\begin{array}{l}\text { Observations on } \\
\text { school premises, in- } \\
\text { cluding the school } \\
\text { yard }\end{array}$ \\
\hline Project 1 & $\begin{array}{l}\text { About140 hours } \\
\text { in total }\end{array}$ & & School premises & $\begin{array}{l}\text { Four docu- } \\
\text { ments }\end{array}$ & $\begin{array}{l}\text { MT teacher } \\
\text { and three class } \\
\text { teachers }\end{array}$ & About 40 hours \\
\hline Project 2 & $\begin{array}{l}5 \text { lessons, } 60 \text { mins } \\
\text { each, from the } \\
\text { Somali classroom }\end{array}$ & 1 lesson & MT classroom & & $\begin{array}{l}\text { MT teacher and } \\
\text { two head teach- } \\
\text { ers }\end{array}$ & About 30 hours \\
\hline
\end{tabular}

students' linguistic diversity, they influenced the research and, in particular, the classroom chosen here, that being the MT classroom for Somali.

The two projects were inspired by linguistic ethnography because of their focus on relations between language use and the social, cultural, economic and sociopolitical contexts that surround the linguistic practice (Creese, 2008; Copland \& Creese, 2015). Linguistic Ethnography enables an analysis of language policy as multilayered (Canagarajah, 2006; Hornberger \& Johnsson, 2017; Zeichner, 2001). In the two projects, data was collected by way of observations in classrooms and the school setting, as well as by way of interviews. Local policy documents were used, such as 1) Policy for Newly Arrived Students' Learning 2) Action Plan for the Reception of Newly Arrived Students with Another Mother Tongue than Swedish, 3) International Development Plan 2014-2016, and 4) Policy on Swedish as a Second Language ${ }^{i i i}$.

Besides the local policy documents, the main data used is from observations in the school, its classrooms (140 hours) and the school yard (70 hours). For this article, in particular observations from one MT classroom will be used, that being the classroom for Somali with students in grade six, aged 12-13 years. Observations of five lessons, 60 minutes each, were documented using field notes and photographs. One lesson was videorecorded. Analyses of policy documents, interviews with teachers and observations on school premises, including the school yard, formed part of the first project. The MT teacher, students and the specific classroom were included in both research projects despite the projects having different aims and focus.

In this linguistic, ethnography-inspired piece of research and not least in the action research project, questions concerning vicinity and respect were crucial. The study was approved by the regional ethics review board. The participating MT teacher, the students and their guardians were informed about the aim of the study, and written consent was given for participation. Because school activities may present challenges, particular regard was shown to ensure that nobody was harmed during the study. Furthermore, material is presented in such a way as to prevent the identification of participants. 
The analysis of the selected MT classroom, a classroom for Somali, is based on Bonacina-Pugh's (2012) three layers focusing on the specific sociocultural context. In the analysis, space for multilingualism has been analysed by identifying physical, temporal and social aspects of space. As a first step, language policy at the management level in Forest School was analysed using policy documents, interviews and field notes from observations at school level. The second step involved the analysis of practised language policy in the Somali MT classroom using schoolscaping, the material used being photographs, fieldnotes from observations and video-recordings in the classroom. In this step, physical, temporal and social aspects of language policy were analysed in relation to the specific room. We approached the material with a focus on i) the location of the classroom within the school, ii) when it is used and iii) by whom the classroom was used. This step also involved the analysis of who has a voice and which language has a place. During the third step the analysis was oriented towards practised language policy using field notes from observations of practices inside and outside the classroom. Here, special interest was directed at temporal and social aspects of spatiality and language norms.

\section{Findings}

To study how language policy at the local school level may create a space for translanguaging in Mother Tongue Tuition, we begin by using Bonacina-Pugh's layers (2012), which focus on the management level and practice level. These we discuss under separate headings below. The analysis of practised language policy starts with physical aspects of the Somali MT classroom, followed by temporal and social aspects.

\section{Language policy at the management level in the selected school}

Forest School is located in an area with high relocation and mobility among inhabitants, and many households can be described as low socio-economic. Due to a large number of people with a Somali background locating there in recent years, the number of students studying Somali in MT was high: in some classes, more than $50 \%$ of students. Access to qualified teachers at the school was limited, but despite this challenge, the school administration, with its head teachers and teachers of Swedish as a second language (SSL), had consciously developed school policy by way of collaboration in study circles, in-service training and team discussions. Here it can be mentioned that not only class teachers but also recreational teachers, MT teachers and Study Guidance Assistants in the Mother Tongue (SGMT assistants, see Rosén, Straszer, \& Wedin, 2019b) took part in at least some of the activities. Also involved were lunchroom and janitorial staff. As evident, work with local school policy involved every staff member, and the focus of activities was to increase their knowledge about the conditions for learning of newly arrived students who did not have Swedish as their mother tongue. The explicit aim of such efforts was to create opportunities for students to develop their language skills, which in turn would increase their ability to learn.

The development work resulted in a local policy for multilingualism and the integration of MT in other school activities. The policy was expressed in formal school documents and could be observed in the school premises as well, through posters, pictures and booklets displayed on the walls of the school and boards where diverse languages were made visible. The school documents that were developed included a Policy on Swedish as a Second language , including issues about assessment and organization of the education. Other policy documents that were developed were an International Development Plan (2014-2016); an Action Plan for the Reception of Newly Arrived Students with Another Mother Tongue than Swedish and Policy for Newly Arrived Students' Learning.

The international development plan identified three areas to prioritise: i) internationalisation, ii) multilingual students' learning and iii) reception and education of newly arrived students. Through various activities, all school staff were expected to find ways to adapt their instruction, and to increase their knowledge and understanding of other languages and cultures from an international perspective. The policy for Newly Arrived Students' Learning stated, with a manifest intertextuality to popular research in the field of multilingualism and intercultural learning, that the school needed to make visible multilingualism by:

- Reading and producing bilingual texts and books

- Cooperating with SGMT assistants and MT teachers

- Including bilingual teaching during the language workshop

- Allowing newly arrived students to write in their MT

- Displaying multilingual posters on the walls

- Displaying students work in their MT

- Using the school blog to inform students and parents about activities in different languages

- Creating teacher exchanges with schools in the UK and Canada

- Corresponding with students in the UK in English and in the MT

- Writing tests in Swedish and English for students to complete, the results of which are then compared 


\section{iejee}

The policy further states that there MT teachers, SGMT assistants and teachers in Swedish as a second language teachers should work together to organise a language workshop for newly arrived students where instruction is in both Swedish and the MT. The Action Plan for the Reception of Newly Arrived Students with Another Mother Tongue than Swedish has a section about MT, stating that MT teachers for Somali and Kurmanji are employed at the school and that having multilingual staff is very important for interculturalism. The policy further states that the presence of MT teachers at school throughout the day, not only after regular school hours, increases opportunities for planning and working together in relation to multilingual students. MT teachers are positioned as "key individuals" in the school setting, as they are able to support other colleagues.

To sum up, the analysis of language policy development at the management level shows that MT teachers are positioned as important because they can support both students and teachers. Previous research (Ganuza \& Hedman, 2015; Jonsson-Lilja, 1999; Svensson \& Torpsten, 2013) highlights the marginalised position of MT teachers; however our analysis shows how the local documents, with explicit reference to popular research in the area of multilingualism, formulate a policy whereby MT teachers are positioned as "key individuals" and where students' MT are to be given space not just in MT but also in the entire school setting.

Practised language policy: physical aspects of the Somali MT classroom

Our analysis of practised language policy begins with the physical aspects. As part of the analysis, we will first present the physical context of the Somali MT classroom.

At this school, the female staff who had a Somali background wore clothes that could be immediately associated with perceptions of Somalia - what we here term Somaliness. With Somaliness we mean features at the school that made identities relating to the geopolitical place of Somalia visible, as well as perceptions about Somalia, iv thus Somaliness as dynamic and negotiated in the local context. One example is a particular type of shawl. Other students also wore shawls, but a specific design became indexical for Somaliness and the use of Somali. Thus, a particular type of shawl was attributed to Somaliness in this particular context, and girls and women who had a Somali background made Somaliness particularly visible by their presence. Somali was also one of several languages that was audible in the school yard, swedish being the most prominent.

A sign in Swedish at the outside doors stated "Take off your shoes". To the right, a large digital screen provided information in both Swedish and some of the more common languages used in the school: at the time of observations, these were (apart from Somali) Kurdish (Kurmanji), Arabic and Finnish. Inside the school, posters and pictures on walls displayed languages, festivals and feasts from different cultures and teachers visiting schools in other countries. To the left in the corridor was the staff room and beyond that the library. The linguistic diversity of the school was apparent in the staff room because of the various language used, notably Somali and Kurdish besides Swedish. The MT teachers, SGMT assistants and teacher assistants at the school also served to increase the visibility of Somali. Class teachers, special needs teachers and school administrators did not have Somali communication skills; however, for one school term, the school did appoint a female class teacher with a Somali background (she had previously worked as an SGMT assistant).

In the library, multilingual material was less prominent than Swedish material. The number of books on the shelves was markedly low considering the number of students. There were some books in some of the language represented at the school, for example Somali, but these were few, and thus Swedish dominated.

The MT classroom was on the first floor, in one of two corridors: it was a former group room between regular classrooms. The door to the classroom had a window on which there was a sign with the text "Modersmål somaliska" [Mother Tongue Somali], together with a map of Somaliavi, the Somali flag and some decorations (see picture 1) (see Straszer et al. 2020 for a more in-depth analysis of the construction of home land). The principal's office, the school nurse's room and the staff office were also located on the first floor. There all regular staff, including MT teachers, each had a desk, while SGMT assistants shared their desks.

\section{Picture 1.}

The sign on the Somali classroom door

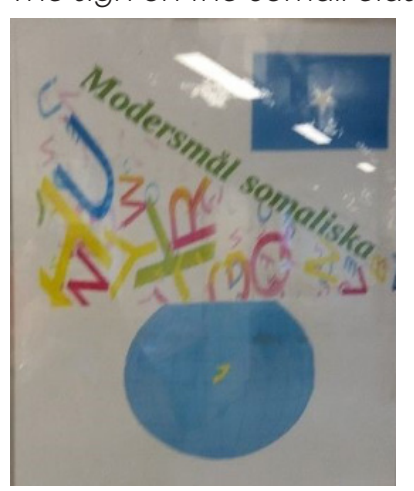

Because of the small size of the classrooms, the school felt crowded. This was also the case with the Somali classroom, as there were as many as 17 students 
sitting close together in groups of three at desks. The classroom had one tall shelving cabinet for student binders and a row of short cabinets. On the walls there were posters and pictures with reference to Somalia and there was a whiteboard on each of two of the walls. During the year of classroom observation, the furnishing did not change; this compares with the placement of students' desks in the regular classroom, which changed frequently during the same period. Pencils and rubbers lay on the desks in the classroom, and students only brought their homework, often in a notebook or photocopied papers. The teacher remained in the room from class to class, with groups of students coming for their lessons but otherwise spending most of their time in the regular classroom. It could therefore be said that the teacher dominated the classroom for Somali to a higher extent in terms of the physical space than teachers in the regular classrooms did. In the regular classrooms, the students spent most of their time and had a permanent desk and drawers for their things.

On the walls were the two aforementioned whiteboards, as well as texts in Swedish with information about the school - for example, a timetable for the for the MT, an excerpt from the curriculum on school values, the code of conduct for the school in general and football specifically, evacuation points and the school term times. There were also posters and pictures in Somali showing words for parts of the body, seasons and handicrafts, as well as maps of Somalia depicting, for example, crops, fruits and regions.

Due to the high number of Somali-speaking students at the school, students from different classes and streams attended MT one class at a time. During the observation period, there were ten groups. The teacher used the two white boards for both longterm information, such as weekly planning, display of curriculum goals (see Picture 2) and information for individual lessons. Somali dominated the room, but certain expressions and words in Swedish were used, both written on the white board and spoken (what the teacher said). The teacher often used Swedish words and expressions relating to the curricula and grading, such as "reading comprehension", "goals to reach" and "assessment", and relating to education, such as essay. Sometimes the teacher used everyday Swedish expressions, such as those meaning "great" and "fantastic question", and for instructions "you are not allowed to write; today, we only only be talking and discussing things". During the observed lessons, students mainly used Somali between themselves. Occasionally, they addressed the teacher in Swedish with questions such as, "May we start to read now?"
Somali-speaking students relatively new to Sweden and others having been born in Sweden and being therefore less competent in Somali; the consequence of this was that they used both Swedish and Somali during individual work. Sometimes, the students with less Somali used Swedish to ask their classmates for help. English was never observed being used in writing but it was in oral communication: for example, a student leaving the classroom one day said: "Bye bye, malim, see you" ("malim" is teacher in Arabic); on another occasion, the teacher said to a student: "Ok well done". It may be the case that the way in which Swedish and English were used was affected by the presence of the researcher. Worth noticing is that students were not asked by either a teacher or another student to consider their choice of language, and this may be perceived to be an acceptance of translanguaging practices, whereby students move freely between languages. In the school, beyond the Somali classroom, Swedish dominated both talking and writing, while expressions of Somali identity were identifiable through students' clothing and language. These expressions were particularly visible because those students attributed a Somali background formed the majority at the school. Overall, however, a Swedish-speaking discourse was reproduced at the school even though school administrators and class teachers as a result of their presence represented to a high extent various types of Swedishness. Despite the display of posters and displays in other languages, the dominant position of Swedish was never challenged during the observations. This became clear as a result of the physical room reserved for MTT in Somali. Meanwhile, the Somali classroom was to a great extent appropriated by the teacher and students. The Somali classroom was made possible as a result of policy decisions at the management level, with the Somali teacher being involved in the policy-making process. The analysis of the MT classroom and its surroundings illustrates the importance of physical space as part of a practised language policy at the school. The Somali room within the context of a Swedish school is a place where the Somali language dominates; in other parts of the school, it has a subordinate position. The students' relation with and sense of belonging to Somalia were evidenced by their use of Somali within the classroom as well as by the cultural artefacts to be found there. However, cultural manifestations of Somalia were not static; rather, they were negotiated and transformed as they intersected within the classroom, while the room also interacted with other spaces within the school. It may, for example, be the case that what was perceived to relate to Somalia here may not signal the same in other settings, such as in Somalia. Thus, one may understand various layers of policy that intersected in this classroom. 


\section{iejee $\approx$}

Practised language policy: temporal aspects of the Somali MT classroom

To further understand created norms, we continue to analyze temporal aspects of practised policy in the MT classroom. In this school, MT was scheduled during regular school hours, with 40 minutes per week for young students and 60 minutes for other students. MT teachers for Somali, Arabic and Kurdish/Kurmanji had permanent employment at the school and were included in work teams with other teachers, class teachers, special needs teachers and SSL teachers. The MT teacher for other languages worked at both Forest School and other schools, but as far as possible maintained the scheduled time for MT. For class 6b, the class selected for this study, MT was on Fridays 10 -11 , and all students in the class studied MT. Of the 21 students in the class, 12 studied Somali.

The limited time for MT is one factor that is relevant for what happens within this temporal space and that also mirrors attitudes on the side of the school administration regarding the status of MT. During her interview, one of the school principals put great emphasis on explaining how work hade been done to integrate MT into the regular school day rather than it being an after-school activity.

An example of this is the fact that the students in $6 \mathrm{~b}$ had recess before coming directly to the classroom for their lesson. If they had homework, they went to the corridor outside their regular classroom, fetching what they needed, usually a notebook. Sometimes the notebooks were in the classroom, and the teacher handed them out at the beginning of the lesson. When students entered the classroom, they sat down often in the same places where they normally sat. No discussions about seating were observed. The observed lessons began with checking attendance and handing out corrected assignments. This was followed by a short review of the previous lesson and a presentation of the current lesson. During the lesson, the teacher had his own laptop on a desk and a folder where he noted student performance. He referred to what was written on the whiteboard and wrote things about the current lesson on the whiteboard. Thus, the lesson was temporally placed in the MT classroom thanks to the weekly planning on the board. Further, the lesson related to curricula and policy documents because the goals were written on the board.
Picture 2.

One of the two whiteboards.

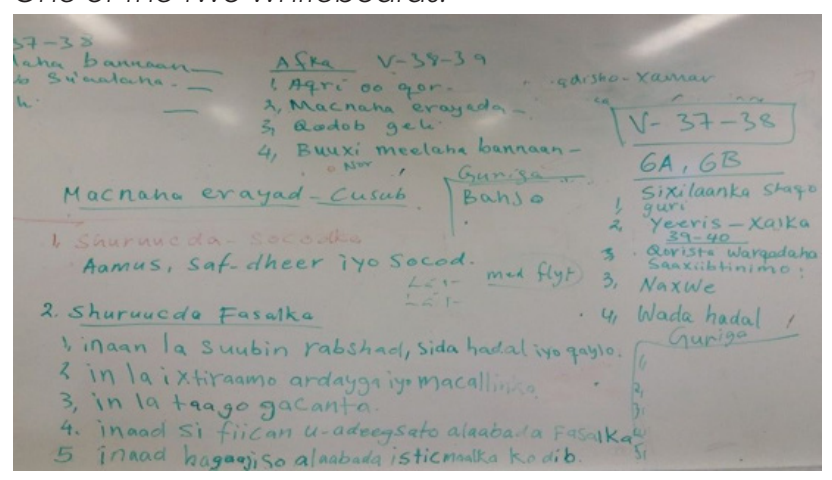

The temporal limitation affects the language norm that appears here, with Somali as the unmarked language, the neutral, and Swedish and English as additional languages. The languages were physically represented by, for example, the teacher's timetable on the wall, which was also the timetable for the classroom, and the weekly plan on the whiteboard (see Picture 2). The sign on the door, the room as physical space, the timetable, the activity plan in weeks as well as the physical presence of the teacher may in the classroom orient the language use of students towards both Somali and Swedish.

Thus, the MT classroom is temporally related to the local school policy by the timetable for all students and, in the classroom, by the teacher's reference to weekly planning on the board. In this case entering the MT classroom may for a newly arrived student mean a space where he/she is perceived as competent student rather than students that lacks Swedish skills and needs extra support. Thus, the existence of the temporal space widens students' space for translanguaging in the school context.

\section{Practised language policy: social aspects of the Somali MT classroom}

The physical and temporal aspects of the MT classroom interact with the social aspects of the space. To analyse social aspects of space as part of a practised language policy, we will present examples of classroom interaction from the observations.

Not once during the observations did students challenge the authority of the teacher. One exception to this may be the occasion when some girls ran giggling from the classroom without first asking the teacher's permission (they wanted to correct one of their shawls in the toilets). After they had been absent for some time, the teacher told the other students that he wanted to go and bring them back. One girl 
objected, saying that they were in the toilets, which mean that he, the teacher, would not be able to. Unlike what might happen in a regular classroom, this teacher did not raise his voice nor reprimand the students by telling them to return to their places, be quiet, listen better and concentrate. On the whole, the classroom was quiet, with students small talking during their work and listening attentively when the teacher talked. Norms and behaviour were not discussed except on a few occasions when the teacher in a low voice asked students to return to their work. In the observed lessons, it was the teacher who initiated and directed the work, and students were not invited to discuss what should be done or how.

The relation between the classroom and students' home environments became apparent when parents visited the MT specifically. On one occasion, the mother of one of the boys came to the lesson. She arrived at the beginning of the lesson with her newborn baby in a stroller and left the school after the lesson. The boy was clearly proud when he went up to the stroller to hug and talk to his sibling. The visit and the boy's action may be interpreted here as being a bridge between the MT classroom and the home.

Thus, the social practices observed in this MT classroom showed that relations both between students and the teacher, and between the school and students' homes followed patterns that differed from those of the regular classroom.

\section{The Somali classroom as a space for translangauging?}

While language policy at the management level appeared to position MT teachers as important actors and MT classrooms as important spaces for students language learning and identity work, the analysis of physical, temporal and social aspects show that the Somali MT classroom is separated from and, at the same time, interacts with other spaces in the school. Thus the classroom constructs as space were Somali and Swedish school discourses intersect and transform. The practised school policy is expressed through the language norms in the separate classroom. An example of this is a newly arrived student, during the lesson in Somali, appearing competent in Somali when, for example, the teacher asked such a student to read a new, more difficult text out loud to the class. Meanwhile, a student who is less competent in Somali can receive support for his or her language development from the classmates and the teacher. Here aspects of power become visible because of the opportunities that the MT classroom creates where the Somali language is perceived as the norm, and where competence and lack of competence in Somali is made visible. This may then be countered by the school as space in the form of time students spend outside MT, where Swedish language competence/ lack of competence becomes apparent for example, when the grading of students' Swedish competence forms part of the assessment.

The analysis of layers of language policy focusing on spatial aspects of this MT classroom made visible how the managed and practised policy intersect each other and their influence on spatial, temporal and social aspects of the MT classroom as translanguaging space. At the same time, the transformation of school and language norms in relation to space was revealed. In terms of the physical room, the MT classroom (as one of many spaces within the school context), and the temporal aspect (60 minutes per school week), the MT classroom constituted a limited translanguaging space with borders, a space where the Somali language was dominant, while outside this space, Swedish was dominant. A Swedish school discourse was apparent in the Somali classroom (the curricula, timetables and values) and was also explicitly referred to, often in Swedish. A Swedish school discourse was also visible in the physical room with the display of texts such as rules of conduct, evacuation plans and other common documents for the school. At the same time, the room was characterised by temporal and social aspects regulating both entrance to and exit from the room, and what took place inside and outside.

At the local management level, the development work at the school involving a multilingual policy and strategies for inclusion of, for example, MT in other school activities was clearly apparent in the form of the physical and temporal room created for the MT classroom in Somali. Although Swedish dominated education outside the MT classroom, it is reasonable to assume that the creation of a specific room for Somali contributed to raising the status of the language while widening students' space to use Somali outside the specific classroom as well.

\section{Discussion}

The analysis of the multilayered language policy at the school shows how the MT classroom was constructed as a space for Somali as well as for other languages. The managed language policy at the school recognised and made visible the linguistic diversity at the school and as a result the Somali language was given status not only within the MT classroom but in the school as a whole as well. Thus, the practised language policy in the MT classroom became more inclusive, as students used both English and Swedish there; it was not a protected space for Somali only. The MT teacher did not perceive the use of Swedish and English in the MT classroom as undermining (perceived language policy) and thus different languages were made visible and audible both inside and outside 
the MT classroom (practised language policy). When linguistic diversity is given space rather than being treated as a threat, translanguaging spaces open for students to develop multilingual identities (Creese \& Blackledge, 2015). Unlike earlier studies, which made visible the marginalised characteristics of MT (Lainio, 2012; Wigerfelt, 2004) and its exclusionary practices (Nilsson \& Bunar, 2016), this study shows how processes of inclusion and exclusion are not fixed but are situated and dynamic.

Based on social aspects, the Somali MT classroom appears to be a translanguaging space since it offers opportunities for varied language use (García, 2009; Zhu et al, 2017), with Somali as the dominant language. At the same time, this classroom differs from the regular classroom (see Wedin, 2017; Wedin, forthcoming) in that students when in it showed more engagement and worked more intensively with given tasks.

With the room physically and temporally within a Swedish school context, the teacher and the students appear to be agents interpreting school policy in different layers (Bonacina-Pugh, 2012; Hornberger \& Johnson, 2017). Here the door may be understood as the boundary between the inside, the context where Somali dominates, and the outside, that being the school context where Swedish dominates. However, as the analysis demonstrates, this boundary is not fixed. The door is admittedly closed but may be opened, for example by the girl adjusting her shawl (who thus appropriates the toilet as a room for that) and by a visiting parent or by students asking for help. Also, temporally the timetable may change, for example, when a school-wide activity, such as a field day, is to take place or when the MT teacher is involved in planning and implementation. Thus, the room should not be understood as being isolated from other rooms but rather as a space for transformation and negotiation of language. This room may therefore be understood to be a translanguaging space where Somali dominates, while it is physically, temporally and socially included in, and to a certain extent secluded from (even if there is some interaction with), the Swedish dominant room of the Forest School, where individual agents may move between layers of power.

The understanding of policy as layered (Blommaert et al., 2005; Hornberger \& Johnson, 2017; Ricento \& Hornberger, 1996) makes visible how language norms transform as they move between layers. It also makes visible how school discourses shift between micro/macro, management/practice and inside/ outside in the creation of space dominated by Somali and Swedish. As Cummins et al. (2015) argue, an environment that promotes the use of Somali inside may increase the opportunity to use Somali outside.

\section{Footnotes}

i. Flerspråkiga resurser (2013-2017), and Modersmålsundervisning och studiehandledning i grundskolan - undervisningens praktik, villkor och pedagogik (2015-2017). The latter was financed by The School Research Fund, Dalarna.

ii. For ethical reasons, all names are fictive.

iii. To safeguard anonymity, no detailed references are provided.

iv. In this text, "Somalia" is used to refer to the geographical area formally called "The Federal Republic of Somalia" formed by rival areas. As the individuals in the text come from different areas, which is not something we deal with here, we simply call this area Somalia and refer to individuals as having a "Somali background". Many of the students referred to in this text have never been to Somalia but have grown up in countries such as Kenya, Ethiopia, Italy and Denmark.

v. "Regular classroom" is used here to refer to the classrooms where students spent most of their classtime, in this case the classroom for $6 \mathrm{~b}$, where they worked with their class teacher.

\section{References}

Avery, H. (2016). Moving Together: Conditions for Intercultural Development at a Highly Diverse Swedish school. PhD diss. Jönköping University, School of Education and Communication.

Baker, C. (2011). Foundations of Bilingual Education and Bilingualism. (5th ed.) Bristol: Multilingual Matters

Ben-Rafael, E., Shohamy, E., Amara, M.H., \& TrumperHecht, N. (2006). Linguistic landscape as symbolic construction of the public space: The case of Israel. International Journal of Multilingualism 3(1), 7-30.

Block, D. (2007). Second Language Identities. London: Continuum.

Blommaert, J. (2013). Ethnography, Superdiversity and Linguistic Landscape: Chronicles of Complexity. Bristol: Multilingual Matters.

Blommaert, J., Collins, J., \& Slembrouck, S. (2005). Spaces of multilingualism. Language \& Communication, 25, 197-216.

Blommaert, J., \& Maly, I. (2014). Ethnographic linguistic landscape analysis and social change: A case study. Working Papers in Urban Language \& Literacies. 133. 
Bonacina-Pugh, F. (2012). Researching 'practiced language policies': Insights from conversation analysis. Language Policy, 11(3), 213-234. DOI: 10.1007/s10993-012-9243-X.

Brown, K. D. (2012). The linguistic landscape of educational spaces: Language revitalization in southeastern Estonia. In D. Gorter, H. F. Marten \& L. Mensel. (Eds.) Minority Languages in the Linguistic Landscape. 281-298. England: Palgrave McMillan.

Canagarajah, A. S. (2006). Ethnographic methods in language policy. In T. Ricento, (ed.) An Introduction to Language policy: Theory and Method. 153-169. Maiden, MA: Blackwell.

Copland, F. \& Creese, A. (2015). Linguistic Ethnography Collecting, Analysing and Presenting Data. Los Angeles: SAGE.

Creese, A. (2008). Linguistic ethnography. In K. King \& N. Hornberger (Eds.) Encyclopedia of Language and Education. (2nd ed) 229-241. New York: Springer.

Creese, A. \& Blackledge, A. (2015). Translanguaging and identity in educational settings. Annual Review of Applied Linguistics 35, 20-35.

Cummins, J. (2005). A proposal for action: Strategies for recognizing heritage language competence as a learning resource within the mainstream classroom. The Modern Language Journal, 89(4), 585-592.

Cummins, J. (2017). Flerspråkiga elever: Effektiv undervisning $i$ en utmanande tid. [Multilingual Students: Effective Education in a Challenging Time] Stockholm: Natur och kultur.

Cummins, J., Hu, S., Markus, P., \& Montero, K. (2015). Identity texts and academic achievement: Connecting the dots in multilingual school contexts. TESOL Quarterly, 49(3), 555-581. DOI: 10.1002/tesq.241

Ganuza, N., \& Hedman, C. (2015). Struggles for legitimacy in mother tongue instruction in Sweden. Language and Education, 29(2), 125139.

García, O. (2009). Bilingual Education in the 21st century: A Global Perspective. Oxford: WileyBlackwell.
Hornberger, N., \& Johnson, D. C. (2017). Slicing the onion ethnographically: Layers and spaces in multilingual language education policy and practice. TESOL Quarterly, 41(3), 509-532.

Hyltenstam,K.\&Milani,T.(2012).Modersmålsundervisning och tvåspråkig undervisning. In K. Hyltenstam, M. Axelsson \& I. Lindberg. (Eds) Flerspråkighet: En forskningsöversikt. [Multilingualism: A Research Overview] 17-152. Vetenskapsrådets rapportserie 5: 2012. Stockholm: Vetenskapsrådet.

Jonsson-Lilja, S. (1999). Den mångkulturella skolan: Ideal kontra verklighet. Modersmålslärarnas arbetsvillkor i Göteborg i ett sociologiskt perspektiv. IPG-rapporter, Nr 1999:12. Institutionen för pedagogik och didaktik, Göteborgs universitet. Göteborg.

Lainio, J. (2012). "Modersmåls erkända och negligerade roller" [The acknowledged and neglected roles of mother tongues]. In M. Olofsson (Ed.) Symposium 2012: Lärarrollen i svenska som andraspråk. [Symposium 2012: The Teacher Role in Swedish as a Second Language] 66-96. Stockholm: Stockholms universitets förlag.

Landry, R. \& Bourhis, R. Y. (1997). Linguistic landscape and ethnolinguistic vitality: An empirical study. Journal of Language and Social Psychology, 16(1), 23-49.

Lefebvre, H. (1991). The Production of Space. Oxford: Blackwell.

Manyak, P. C. (2004). "What did he say?" Translation in a primary-grade English immersion class. Multicultural Perspectives, 137(2), 12-18. DOI: 10.1207/S15327892mcp0601_3

Nilsson, J., \& Bunar, N. (2016). Educational responses to newly arrived students in Sweden: Understanding the structure and influence of post-migration ecology. Scandinavian Journal of Educational Research, 60(4) 399-416.

Norberg Brorsson, B., \& Lainio, J. (2015). Litteratur och språk: Flerspråkiga elever och deras tillgång till utbildning och spark i skolan: Implikationer för lärarutbildningen. Uppföljningsrapport till EUCIM-TE-projektet. Nr: 10, 2015. Mälardalens högskola. Eskilstuna.

Norton, B. (2013). Identity and Language Learning: Extending the Conversation. Bristol: Multilingual Matters. 


\section{iejee $\approx$}

Paulsrud, B., Rosén, J., Straszer, B. \& Wedin, Å. (Eds.) (2017). New Perspectives on Translanguaging and Education. Bristol: Multilingual Matters.

Pavlenko, A. \& Blackledge, A. (2004). Introduction: New Theoretical Approaches to the Study of Negotiation of Identities in Multilingual Contexts. I A. Pavlenko \& A. Blackledge, (Eds.) Negotiations of Identities in Multilingual Contexts. 1-33. Clevedon: Multilingual Matters.

Reath Warren, A. (2013). Mother tongue tuition in Sweden: Curriculum analysis and classroom experience. International Electronic Journal of Elementary Education, 6 (1), 115-142.

Ricento, T. \& Hornberger, N. H. (1996). Unpeeling the onion: Language planning and policy and the ELT professional. TESOL Quarterly, 30(3), 401-427.

Rosén, J., Straszer, B. \& Wedin, Å. (2019a). Maintaining, developing and revitalizing: Language ideologies in national education policy and home language instruction in compulsory school in Sweden. In C. Seals \& V. OlsenReeder. (Eds.) Embracing Multilingualism across Educational Contexts. 182-211. New Zealand: Victoria University of Wellington.

Rosén, J., Straszer, B. \& Wedin, ^. (2019b). Studiehandledning på modersmål: Studiehandledares positionering och yrkesroll. [Study Guidance assistance in the Mother Tongue: SGMT Assistants' positioning and professional role] Educare - Vetenskapliga Skrifter (3), 49-61. https://doi.org/10.24834/ educare. 2019.3.4

Rönnlund, M., \& Tollefsen, A. (2016). Rum: Samhällsvetenskapliga perspektiv. [Space: Perspectives from Social Sciences] Stockholm: Liber.

SFS 2010:800 Skollag. [Education Act]. Swedish Code of Statutes. Stockholm: Ministry of Education and Research.

Shohamy, E., \& Gorter, D. (2009). Linguistic Landscape: Expanding the Scenery. New York and London: Routledge.

SI (2012). I marginalen: En granskning av modersmålsundervisning och tvåspråkig undervisning i de nationella minoritetsspråken. [In the Margain: Examination of Mother Tongue Education and Bilingual Education in the national Minority Languages] Kvalitetsgranskning. Rapport 2012: 2. The Swedish Schools Inspectorate: Stockholm: Skolinspektionen.
Skolverket (2008). Med annat modersmål: Elever i grundskolan och skolans verksamhet. [With other Mother Tongue: Students in Primary school and School Activities] Rapport 321. Stockholm: skolverket.

SNAE (2018). Läroplan för grundskolan, förskoleklassen och fritidshemmet. [Curriculum for the Compulsory School, Preschool Class and the Recreation Centre]. Revised 2018. Stockholm: Swedish National Agency for Education.

Spetz, J. (2014). Debatterad och marginaliserad: Perspektiv på modersmålsundervisningen. [Debated and Marginalised: Perspectives on Mother Tongue Education] Rapporter från Språkrådet 6. Språkrådet. Stockholm.

Spolsky, B. (2004). Language Policy. Cambridge: Cambridge University Press.

Straszer, B. (2017). Translanguaging space and spaces for translanguaging: A case study of a Finnish-language pre-school in Sweden. In B. Paulsrud, J. Rosén, B. Straszer \& A. Wedin, (Eds.) New Perspectives on Translanguaging and Education. 129-147.Bristol: Multilingual Matters.

Straszer. B. \& Kroik, D. (in press). Promoting indigenous language rights in Saami educational spaces: Findings from a preschool in southern Saepmie. In E. Krompák, Edina; V. Fernández-Mallat \& S. Meyer (Eds.) Linguistic Landscape and Educational Spaces. Bristol: Multilingual Matters.

Straszer, B., Rosén, J. \& Wedin, Å. (2020). Imagining the homeland. Transnational spaces in mother tongue tuition in Sweden. Journal of Multicultural Discourse. DOI:10.1080/17447143.20 20.1726932

Straszer, B., Rosén, J. \& Wedin, Å. (submitted). Spaces for translanguaging in mother tongue tuition.

Straszer, B. \& Wedin, Å. (2018). Rum för transspråkande i modersmålsundervisning. [Space for translanguaging in mother tongue tuition.] In B. Paulsrud, J. Rosén, B. Straszer \& $\AA$. Wedin. (Eds.) Transspråkande i svenska utbildningssammanhang. [Translanguaging in Swedish Educational Settings] 217-241. Lund: Studentlitteratur.

Svensson, G. \& Torpsten, A.-K. (2013). Makt och litteracitet: Modersmålslärare skriver om modersmålsundervisning. In D. Skjelbred \& A. Veum (Eds.) Literacy i læringskontektser. 170-179. Oslo, Cappelen Damm AS. 
Szabó, T. P. (2015). The management of diversity in schoolscapes: An analysis of Hungarian practices. Apples - Journal of Applied Language Studies, 9 (1), 23-51.

Wedin, A. (2017). Arbete med identitetstexter Flerspråkigt skrivande för identitetsförhandling och engagemang. [Working with Identity Texts - Multilingual Writing for Negotiation of Identity and Engagement] Nordisk tidskrift för andraspråksforskning. 13(1), 45-61.

Wedin, A. \& Wessman, A. (2017). Multilingualism as policy and practices in elementary school: Powerful tools for inclusion of newly arrived pupils. International Electronic Journal of Elementary Education, 9(4), 873-890.

Wedin, Å. (In press). Construction of identities in diverse classrooms: Writing identity texts in grade five. In E.O. Breuer, E. Lindgren, A. Stavans \& E. Van Steendam, (Eds.) Multilingual Literacy. Bristol: Multilingual Matters.

Wei, Li (2011). Moment analysis and translanguaging space: Discursive construction of identities by multilingual Chinese youth in Britain. Journal of Pragmatics, 43(5), 1222-1235.

Wigerfelt, B. (2004). Modersmålslärare: En yrkesgrupp mellan retorik och realitet. [Mother Tounge Tutors: A Professional Group between Rhetoric and Reality] In M. Greiff, A. Persson \& H. Viggósson (Eds.) Nära gränsen? Perspektiv på skolans arbetsliv. [Close to the Border? Perspectives on Working Life in School] 221-255.) Malmö: Arbetslivsinstitutet.

Zeichner, K. (2001). Educational action research. In P. Reason \& H. Bradbury. (Eds.) Handbook of Action Research: Participative Inquiry and Practice. 273-283. London: Sage.

Zhu, H., Li, W. \& Lyons, A. (2017). Polish shop(ping) as translanguaging space. Social Semiotics, 27 (4), 411-433. doi-org.www.bibproxy.du. se/10.1080/10350330.2017.1334390 